\title{
Second messengers, ion channels and pharmacology of airway smooth muscle
}

\begin{abstract}
I.P. Hall
Second messengers, ion channels and pharmacology of airway smooth muscle. I.P. Hall. (C) ERS Journals Ltd 2000.

ABSTRACT: The airway smooth muscle cell is the chief effector cell governing the control of airway calibre in the human lung. The contractile state of the airway smooth muscle cell is predominantly influenced by the balance of constrictor and relaxant stimuli.

Agents such as histamine and acetylcholine cause airway smooth muscle cells to contract through activation of specific cell surface receptors and engagement of signal transduction pathways and/or ion channels. The predominant pathway mediating constriction is activation of phospholipase $C$, with release of inositol 1,4,5-triphosphate and elevation of intracellular calcium levels.

Relaxation is brought about predominantly by stimulation of adenylyl cyclase-coupled receptors (e.g. the $\beta_{2}$-adrenoceptor) resulting in elevation of cell cyclic adenosine monophosphate content. Complex crosstalk occurs between both of these pathways and also ion channels expressed on the airway smooth muscle cell membrane, leading to careful regulation of airway smooth muscle tone.

A greater understanding of the mechanisms governing control of these pathways will lead to the identification of novel therapeutic targets which will in turn lead to new agents for the treatment of asthma.

Eur Respir J 2000; 15: 1120-1127.
\end{abstract}

The airway smooth muscle cell is critically important in asthma, mediating not only the bronchoconstrictor effects of agents such as histamine and methacholine but also the bronchodilator effects of $\beta_{2}$-agonists. In principle, an understanding of the mechanisms underlying control of the airway smooth muscle cell is important in defining the pathophysiological abnormalities present in asthma and other airway diseases. Both the contractile and relaxant responses of airway smooth muscle are regulated by crosstalk between the important intracellular signalling pathways controlling contraction and relaxation. This review summarizes the key processes involved in the regulation of these two responses in airway smooth muscle. Although many of these pathways are complex, it is important that understanding of these processes is increased. Most therapeutic agents currently in use as bronchodilators interact with these pathways, and novel targets exist which can potentially be exploited in the development of new asthma therapies.
Division of Therapeutics, University Hospital, Nottingham, UK.

\author{
Correspondence: I.P. Hall \\ Division of Therapeutics \\ C Floor South Block \\ University Hospital \\ Nottingham \\ NG7 2UH \\ UK \\ Fax: 441159422232
}

Keywords: $\beta$-Adrenergic receptor cyclic adenosine monophosphate $\mathrm{G}$ protein-coupled receptors ion channels

phosphodiesterases

Received: November 181999

Accepted after revision January 122000

Previous articles in this series: No. 1: S.J. Gunst, D.D. Tang. The contractile apparatus and mechanical properties of airway smooth muscle. Eur Respir J 2000; 15: 600-616. No. 2: A. James, N. Carrol. Airway smooth muscle in health and disease; methods of measurement and relation to function. Eur Respir J 2000; 15: 782-789. No. 3: K.F. Chung. Airway smooth muscle cells: contributing to and regulating airway mucosal inflammation? Eur Respir J 2000; 15: 961-969.

Before discussing the regulation of contractile and relaxant responses in airway smooth muscle in detail, it is important to consider the model systems in which these processes have been studied. Obviously, the most relevant system to patients with respiratory disease is tissue derived from human subjects. However, limited amounts of tissues (especially from asthmatic individuals) have been available and hence there are few published data on human airway smooth muscle ex vivo. The majority of published data involve either ex vivo studies of airway smooth muscle from animals (e.g. guinea-pig or bovine trachea) or, more recently, airway myocytes in primary culture. Both of these systems have potential drawbacks. Although experimental animal airway smooth muscle has many similarities to human airway smooth muscle, there are subtle differences, e.g. in the receptor subtype expressed or in the relative balance between the inflammatory mediators present in 
preparations. Conversely, using cultured airway smooth muscle, which allows human tissue to be utilized, imposes a different series of problems because of the dedifferentiation that occurs during cell culture [1]. Thus, following subculture, human airway smooth muscle cells show reduced expression of contractile protein elements [2], a number of important ion channels and some receptor subtypes (e.g. the muscarinic $\mathrm{M}_{3}$ receptor) [3], whereas other receptors (e.g. prostanoid receptors) appear to be upregulated in cultured cell systems [4]. Recently, a number of groups have attempted to redifferentiate airway smooth muscle by altering culture conditions, often utilizing extended periods of growth arrest $[5,6]$. Preliminary data suggest that this may result in a return to a more differentiated phenotype. However, to date, the majority of published data using cultured airway smooth muscle have been performed on cells which are at least partially dedifferentiated and which perhaps would be best called airway myofibroblasts.

\section{Contractile responses}

Following stimulation of airway smooth muscle by classical contractile agonists such as histamine or methacholine, initiation of the contractile response depends upon stimulation of phospholipase C-dependent pathways [7, 8] (fig. 1). These pathways have been extensively studied in cultured and noncultured airway myocytes from a range of species, although, because of difficulty in obtaining adequate amount of tissue, the majority of human studies have been performed using cultured cell systems [9]. The key intracellular signalling steps involved in the contractile response are shown in figure 1 using histamine as a

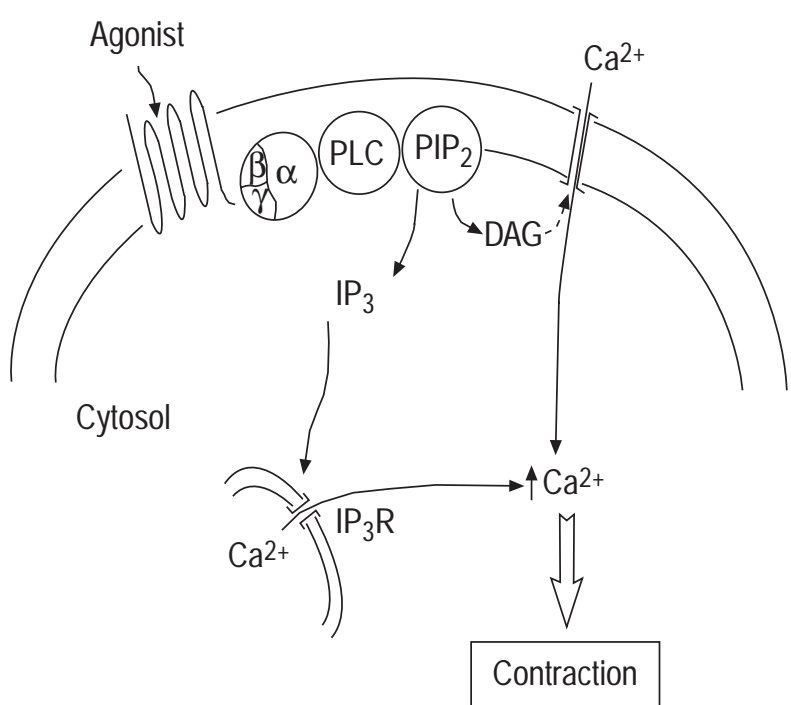

Fig. 1. - Pathways involved in airway smooth muscle contraction. Following binding of agonist to receptor in the cell membrane, the associated $G$ protein which exists as a heterotrimeric complex of $\alpha, \beta$ and $\gamma$ subunit dissociates: the free $\alpha$ subunit stimulates phospholipase C (PLC) which in turn catalyses the breakdown of phosphatidylinositol 4,5 biphosphate $\left(\mathrm{PIP}_{2}\right)$. This results in the formation of the two intracellular messengers diacylglycerol (DAG) and inositol 1,4,5 triphosphate $\left(\mathrm{IP}_{3}\right)$. $\mathrm{IP}_{3}$ is able to release calcium from intracellular stores via the $\mathrm{IP}_{3}$ receptor $\left(\mathrm{IP}_{3} \mathrm{R}\right.$ ), whereas DAG, in addition to activating protein kinase $\mathrm{C}$ (not shown), may also be able to stimulate calcium entry. The rise in cytosolic free calcium levels leads to contraction of the airway smooth muscle cell. paradigm. Histamine binds to the histamine $\mathrm{H}_{1}$ receptor present on the cell surface: this receptor is a member of the seven transmembrane domain $G$ protein-coupled receptor superfamily which is responsible for the action of most important agonists in airway smooth muscle [10]. Binding of histamine to the $\mathrm{H}_{1}$ receptor results in stimulation of the associated $\mathrm{G}$ protein, $\mathrm{Gq}$, which dissociates releasing the active $\alpha$ subunit which is able to stimulate phospholipase $\mathrm{C}$. This enzyme stimulates the breakdown of the membrane phospholipid phosphatidyl inositol 4,5 bisphosphate $\left(\mathrm{PIP}_{2}\right)$, resulting in the production of the two intracellular second messengers inositol 1,4,5 triphosphate $\left(\mathrm{IP}_{3}\right.$ and diacylglycerol (DAG). $\mathrm{IP}_{3}$ diffuses through the cytosol and binds to specific sites (the $\mathrm{IP}_{3}$ receptor) on intracellular calcium stores, resulting in release of calcium from the intracellular stores into the cytoplasm. This produces a brief rise in the intracellular free calcium concentration. DAG, the other product of $\mathrm{PIP}_{2}$ hydrolysis, is able to activate protein kinase $\mathrm{C}$, which in turn can phosphorylate key targets, resulting in an altered sensitivity of the contractile apparatus to calcium. Recently, it has also been suggested that DAG may have an additional role as an agonist for nonvoltage-dependent calcium channels present in the tissue.

A number of other contractile agonists coupled to receptors expressed on airway smooth muscle are also able to stimulate contractile responses through the same intracellular signalling pathway. These agonists, and, where characterized, the receptors through which they operate, are shown in table 1.

\section{Control of intracellular calcium concentration}

If the intracellular calcium response to an agonist such as histamine is followed in freshly isolated airway smooth muscle, cultured airway smooth muscle or permeabilized strips of tracheal muscle, a characteristic profile of intracellular calcium levels following agonist stimulation is observed (fig. 2) [20]. Experiments designed to study intracellular calcium signalling have utilized a range of calcium-sensitive fluorescent probes which can be trapped inside the cell such as Fura 2 and Fluo 3. Combining the use of cells "loaded" with these agents with sophisticated imaging methods allows changes in calcium levels in single living cells to be followed in "real time" [18, 21]. Following stimulation of a cell with agonist, an initial rapid rise in intracellular calcium levels occurs. This reaches a maximum within $10-15 \mathrm{~s}$ and then rapidly declines

Table 1. - Contractile agonists in airway smooth muscle and their receptors

\begin{tabular}{|c|c|c|c|}
\hline [Ref.] & Agonist & Receptor & Comments \\
\hline [10] & Histamine & $\mathrm{H}_{1}$ & \\
\hline [11-14] & Acetylcholine & $\mathrm{M}_{3}$ & $\begin{array}{l}\mathrm{M}_{2} \text { also present, role } \\
\text { unclear }\end{array}$ \\
\hline$[15]$ & Leukotriene $\mathrm{D}_{4}$ & & \\
\hline [16] & Substance P & $? \mathrm{NK}_{2}$ & \\
\hline$[17,18]$ & Bradykinin & $\mathrm{B}_{2}$ & $\begin{array}{l}\text { Some evidence for } \\
\text { atypical bradykinin } \\
\text { receptors ? } \mathrm{B}_{3}\end{array}$ \\
\hline [19] & $\begin{array}{l}\text { 5-Hydroxytryp- } \\
\text { tamine }\end{array}$ & $? 5-\mathrm{HT}_{2}$ & $\begin{array}{l}\text { Subtype not fully } \\
\text { defined }\end{array}$ \\
\hline
\end{tabular}




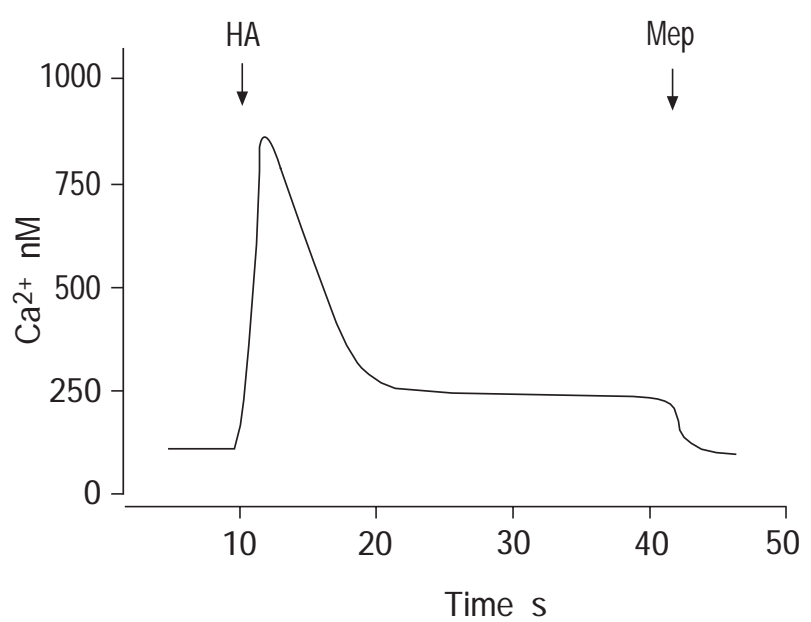

Fig. 2. - Calcium transient in Fura 2-loaded airway smooth muscle cell. Following stimulation with histamine (HA), basal calcium levels rise from $\sim 100 \mathrm{nM}$ to a peak of $0.5-1 \mu \mathrm{M}$ before falling to a sustained plateau phase. This plateau phase is dependent upon entry of calcium across the cell membrane (see text) and the continued presence of agonist: addition of the histamine $\mathrm{H}_{1}$ receptor antagonist mepyramine (Mep) results in a fall back to basal calcium levels.

again and is dependent upon release of calcium from intracellular stores. This is mediated by agonist-induced $\mathrm{IP}_{3}$ production and subsequent stimulation of $\mathrm{IP}_{3}$ receptors on the sarcoplasmic reticulum as discussed above [7]. The precise mechanism whereby calcium concentrations subsequently fall to resting levels is less clear, although reuptake into stores is the most likely explanation: calcium pumps can extrude calcium from the cell but the time course of the observed response seems too rapid for this mechanism to be important. However, in the continued presence of agonist, calcium levels do not fall completely back down to baseline levels, and a sustained plateau response is usually observed (fig. 2) [20]. This sustained calcium response is important for maintaining the contractile response to agonist. It is clear that the source of calcium for the maintained "plateau phase" of the calcium response is an influx of calcium from extracellular sources: if extracellular calcium concentrations are reduced to submicromolar levels, the plateau phase is lost. The sustained calcium entry occurs through a channel (or channels) mechanism which remains poorly characterized [20]. Two models for calcium influx have been proposed: 1) a capacitative calcium entry which is stimulated by store emptying; and 2) a noncapacitative entry pathway independent of store emptying but dependent upon receptor activation of specific channels [21]. The molecular identity of calcium entry pathways in airway smooth muscle has remained obscure, although recent data from recombinant cell systems has suggested that homologues of the Drosophila transient receptor potential $(T R P)$ gene family may be potential candidates [22]. At present there are seven known human members of the TRP gene family (HTRP), of which HTRP1, -3, -4 and -6 are potential calcium entry pathways which are expressed in cultured human airway smooth muscle [23]. The recent observation that HTRP3 can be stimulated by DAG provides an attractive mechanism for sustained calcium entry in nonexcitable cells, although whether this is important in airway smooth muscle remains to be determined, and, indeed, HTRP4 exhibits characteristics more akin to the electrophysiological features of the putative airway myocyte channel.

\section{Relaxation through Gs-coupled receptors}

Airway smooth muscle cells express at least two receptors coupled to adenylyl cyclase via a stimulatory $\mathrm{G}$ protein (Gs), namely the $\beta_{2}$-adrenoceptor $[4,24,25]$ and a prostanoid receptor (probably $\mathrm{EP}_{2}$ ) $[4,26]$ : there may be, in addition, a small population of vasoactive intestinal peptide receptors, at least in some species [27, 28]. Stimulation of adenylyl cyclase-coupled receptors results in Gs $\alpha$ dependent activation of adenylyl cyclase in a manner analogous to activation of phospholipase $\mathrm{C}$ pathways: thus, following binding of an agonist such as salbutamol to the $\beta_{2}$ adrenoceptor, Gs dissociates and the active $\alpha$ subunit of Gs stimulates adenylyl cyclase activity (for review, see [29]). Adenylyl cyclase catalyses the breakdown of adenosine triphosphate (ATP) to cyclic adenosine monophosphate (AMP) and cyclic AMP in turn is able to activate protein kinase $\mathrm{A}$, which phosphorylates key intracellular proteins and thus is responsible for the majority of the physiological response to stimulation of $\beta_{2}$-adrenoceptors (fig. 3). Cyclic AMP is broken down by intracellular phosphodiesterases (see below). Airway smooth muscle also contains a population of muscarinic $\mathrm{M}_{2}$ receptors which are negatively coupled to adenylyl cyclase via an inhibitory $\mathrm{G}$ protein $(\mathrm{Gi})$ [30-32]. Stimulation of muscarinic $\mathrm{M}_{2}$ receptors by acetylcholine inhibits activation of adenylyl cyclase, which results in an acute lowering of intracellular cyclic AMP levels. Thus intracellular cyclic AMP concentration is controlled by the counterbalance between activation of Gs-coupled receptors and $\mathrm{Gi}$-coupled receptors together with regulation at the level of breakdown of cyclic AMP by phosphodiesterase isoforms (see below).

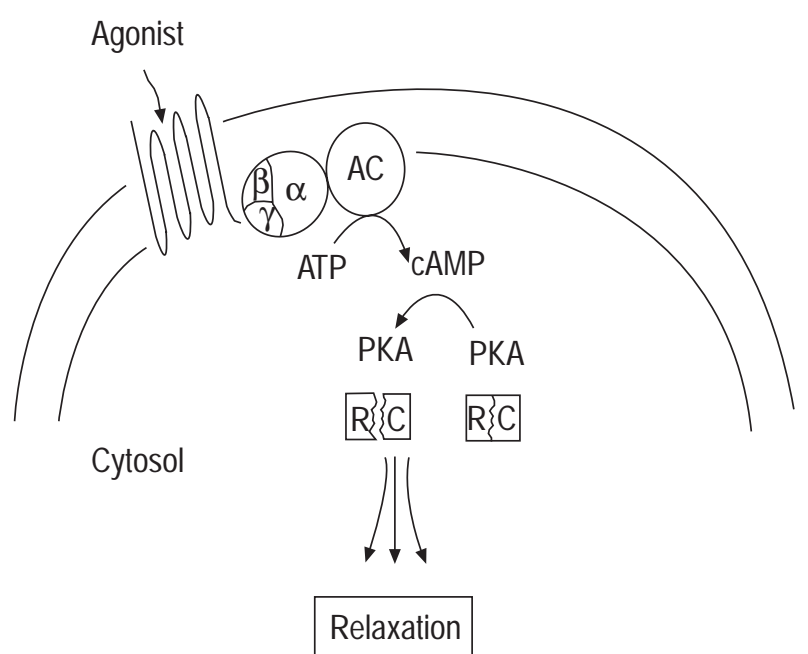

Fig. 3. - Pathways involved in airway smooth muscle relaxation. Following binding of agonist to receptor (e.g. the $\beta_{2}$ adrenoreceptor), the associated stimulatory $\mathrm{G}$ protein (Gs) dissociates freeing the stimulatory $\alpha$ subunit from $\beta \gamma$. Gs $\alpha$ is able to activate adrenylyl cyclase (AC), which catalyses the breakdown of adenosine triphosphate (ATP) to cyclic adenosine monophosphate (cAMP); this in turn activates protein kinase A (PKA), leading to the dissociation of the catalytic subunit (C) from the regulatory subunit $(\mathrm{R})$. The catalytic subunit is able to phosphorylate key targets within the cell leading to relaxation. 
There are a number of targets for protein kinase A which can potentially result in relaxation of airway smooth muscle. These are summarized in table 2. Because membrane hyperpolarization causes myocyte relaxation, stimulation of the calcium-activated potassium channel $\left(\mathrm{K}_{\mathrm{Ca}}\right.$, also called BK or Maxi $\mathrm{K}$ ) results in relaxation [33]. The mechanisms underlying regulation of $\mathrm{K}_{\mathrm{Ca}}$ have been dissected over the last few years and it is now clear that this channel is subject to complex regulation, being stimulated by both Gs $\alpha$ directly [34] and the catalytic subunit of protein kinase $\mathrm{A}$ [35]. In addition, $\mathrm{K}_{\mathrm{Ca}}$ is inhibited by $\mathrm{Gi \alpha}$ directly following stimulation of musearinic receptors (presumably $\mathrm{M}_{2}$ ) $[36,37]$. An increase in channel activity results in membrane hyperpolarization and relaxation [38]. Whether this remains the key effector pathway for cyclic AMP/protein kinase A-mediated relaxation remains uncertain, although toxin inhibitors of this channel such as charybdotoxin and iberiotoxin potently antagonize the relaxant effect of $\beta_{2}$-agonists on strips of airway smooth muscle $[33,38]$. Other potential targets for protein kinase A include altering the phosphorylation state of myosin light chain kinase and/or the contractile apparatus within the cell, and promoting calcium extrusion (table 2) $[39,40]$.

\section{Cyclic guanosine monophosphate and airway smooth muscle}

As mentioned above, agents which elevate cyclic guanosine monophosphate (GMP) levels such as sodium nitroprusside are able to bring about the relaxation of airway smooth muscle preparations in organ bath systems. The potential importance of cyclic GMP in relaxant responses in airway (as opposed to vascular) smooth muscle in vivo is unclear. Potential stimulants of guanylyl cyclase in vivo include atrial natriuretic peptide (ANP) and nitric oxide. ANP is predominantly produced in the heart, and plasma ANP levels have been shown to be elevated during exercise and acute episodes of asthma [41, 42]. Sodium nitroprusside, ANP and the related brain natriuretic peptide have all been shown to cause elevation of the cyclic GMP content of cultured human airway smooth muscle [43]. NO has also been shown to cause airway smooth muscle to relax in vitro [44]: NO is probably produced primarily from the epithelium following stimulation with agents such as bradykinin. In keeping with this, bradykinin is able to cause elevation of cyclic GMP levels and relaxation

Table 2. - Mechanisms underlying airway smooth muscle relaxation by $\beta_{2}$-agonists

\section{Cyclic AMP-dependent}

Inhibition of inositol phospholipid hydrolysis

Stimulation of $\mathrm{K}_{\mathrm{Ca}}$

Membrane hyperpolarization

Inhibition of myosin light chain kinase activation

Alteration of phosphorylation state of contractile apparatus

Increased $\mathrm{Ca}^{2+}$ reuptake/extrusion

Cyclic AMP-independent

Stimulation of $\mathrm{K}_{\mathrm{Ca}}$ by $\mathrm{G}_{\mathrm{s} \alpha}$

AMP: adenosine monophosphate; $\mathrm{K}_{\mathrm{Ca}}$ : calcium activated potassium channel; Gs $\alpha$ : $\alpha$ subunit of stimulatory $\mathrm{G}$ protein. of guinea pig tracheal muscle in preparations containing intact epithelium but not those which are epitheliumdenuded $[45,46]$.

The mechanisms underlying cyclic GMP-induced relaxation are less clear than those underlying cyclic AMPinduced relaxation. Cyclic GMP is able to activate cyclic GMP-dependent protein kinase (PKG), and at higher concentrations can also activate protein kinase A [47]. Cyclic GMP-dependent protein kinase is able to mimic many of the actions of protein kinase A including effects on calcium homeostasis, altering the sensitivity of contractile proteins to calcium and membrane hyperpolarization via activation of $\mathrm{K}_{\mathrm{Ca}}$ [47-55]. There may also be indirect effects of cyclic GMP via its ability to inhibit the type 3 cyclic GMP-inhibited cyclic AMP-selective phosphodiesterase present in airway smooth muscle (see below). Elevation of cyclic GMP levels in airway smooth muscle occurs as a result of increased activity of guanylyl cyclase. Two different major forms of guanylyl cyclase, soluble (cytosolic) and particulate guanylyl cyclase exist. Whereas ANP interacts with the particulate form of guanylyl cyclase, NO interacts with the soluble form. Little is known about the isoforms of guanylyl cyclase present in airway smooth muscle, although the $\alpha_{1} / \beta_{1}$ form of soluble guanylyl cyclase has been identified in bovine lung [56].

\section{Crosstalk between signalling pathways}

In addition to the responses described above, complex crosstalk occurs between signalling pathways in many cell types including airway smooth muscle [57]. For example, elevation of cellular cyclic AMP content inhibits signalling through phospholipase $\mathrm{C}$ pathways, thus counteracting the effect of contractile agonists such as histamine [58-61]. This inhibitory mechanism is dependent upon activation of protein kinase A and occurs at the postreceptor level, presumably at the level of phospholipase $\mathrm{C}$ itself [59]. However, even crosstalk is agonist-dependent: in contrast to histamine-induced $\mathrm{PIP}_{2}$ hydrolysis, cholinergic agonist-induced inositol phosphate responses are not inhibited to any major extent by $\beta_{2}$-agonist-induced elevation of cellular cyclic AMP content, although the phosphodiesterase type IV inhibitor rolipram is able to inhibit this response [62]. As discussed above, stimulation of $\mathrm{M}_{2}$ receptors inhibits cyclic AMP formation in airway smooth muscle. It can thus be seen that, in airway smooth muscle, a series of complex controlling mechanisms have evolved which have resulted in cholinergic stimulation resulting in both contraction through stimulation of phospholipase C-dependent pathways and also inhibition of relaxation through acute inhibition of adenylyl cyclase (and thus inhibition of cyclic AMP-dependent relaxation pathways). Even this may be more complex than initially thought: recent data have suggested that prolonged stimulation of muscarinic $\mathrm{M}_{2}$ receptors may in fact sensitize adenylyl cyclase and thus the $M_{2}$ receptor present on airway smooth muscle may subserve two roles, with acute inhibition of adenylyl cyclase but longterm homeostatic regulation serving to upregulate adenylyl cyclase expression and thus counteract the action of muscarinic agonists at $\mathrm{M}_{3}$ receptors coupled to phospholipase C [63]. 


\section{Phosphodiesterases}

Although theophylline has been used clinically for many years and is a relatively weak relaxant of airway smooth muscle preparations in organ bath systems, it has recently become clear that many different isoforms of phosphodiesterase exist. Molecular cloning approaches have revealed the existence of at least seven phosphodiesterase families, each family containing a number of variants, some resulting as a consequence of alternative splicing of gene family members [64]. In airway smooth muscle, the most important phosphodiesterase isoforms appear to be members of the type III and type IV families [4, 65-67]. Physiological control of cellular cyclic AMP content (by regulating cyclic AMP breakdown) appears to be predominantly due to the type IV isoform with a variable contribution from type III phosphodiesterase dependent upon the species studied. The two families can be distinguished by their regulatory characteristics: whereas both the type III and type IV phosphodiesterase families are relatively cyclic AMP-selective, members of the type III phosphodiesterase family are stimulated by cyclic GMP. As discussed above, relatively little attention has been paid to cyclic GMP as a mediator of relaxation in airway smooth muscle (as opposed to vascular smooth muscle, in which cyclic GMP has a clear-cut role).

\section{Ion channels in airway smooth muscle}

Airway smooth muscle cells exhibit marked stability of the membrane potential, which is dependent predominantly on the activity of a range of $\mathrm{Ca}^{2+}, \mathrm{K}^{+}$and $\mathrm{Cl}^{-}$channels. In some species (including human), slow wave activity is observed.

\section{Calcium channels}

There are a number of forms of voltage-dependent calcium channel which differ in their selectivity for divalent cations and their sensitivity to antagonists. Of the five main families (T, L, M, R and P/Q), the most important in most smooth muscle types is probably the L type channel. The channels are formed by hetero-oligomeric complexes consisting of an $\alpha_{1}$ subunit which forms the pore of the channel and provides the extracellular binding site for most agonists and antagonists together with a $\beta, \alpha_{2}-\delta$ and possibly $\gamma$ subunit. Although voltage-dependent calcium channels can be readily identified in freshly isolated airway myocytes and channel activity is increased by cholinergic agents such as methacholine, the overall contribution of these channels to agonist-induced contractile responses seems small. As mentioned above, the prolonged rise in intracellular calcium levels seen following stimulation with agonists such as histamine is insensitive to classical voltage-dependent calcium channel antagonists, in addition, these agents are poor bronchodilators [68-72].

\section{Chloride channels}

A large number of chloride channels have now been identified and these fall into three major groupings, voltage-sensitive chloride channels (CIC-2 to -5), volume- regulated chloride channels and another group including the cystic fibrosis transmembrane conductance regulator and the calcium-activated chloride channel. Relatively little work has been carried out on chloride channel expression in airway smooth muscle, although airway smooth muscles express a calcium-activated chloride current. These channels activate briefly following intracellular calcium release but are rapidly phosphorylated by calcium/calmodulin-dependent protein kinase, thus leading to uncoupling of the channel from regulation by cytosolic calcium [73].

\section{Potassium channels}

As has already been mentioned, potassium channels are also likely to be important in the control of membrane potential in airway smooth muscle cells $[74,75]$. Under resting conditions, the membrane potential of airway smooth muscle cells is remarkably constant due to strong outward rectification. This is probably due to the presence of a delayed rectifier channel [76]. In addition, following stimulation with agents able to cause elevation of intracellular cyclic AMP levels, the high-conductance calciumsensitive potassium channel is activated: as mentioned above this is likely to be important in producing at least part of the relaxant response to $\beta_{2}$-agonists [33-35]. ATPsensitive potassium channels $\left(\mathrm{K}_{\mathrm{ATP}}\right)$ are also present in airway smooth muscle, although the lack of effectiveness of activators of $\mathrm{K}_{\mathrm{ATP}}$ such as levcromakalin or antagonists of $\mathrm{K}_{\mathrm{ATP}}$ such as glibenclamide in vivo on airway tone imply that $\mathrm{K}_{\mathrm{ATP}}$ is unlikely to be critically important in the regulation of contractile or relaxant responses in airway smooth muscle [77]. Recent molecular studies on the nature of the potassium channel subunits expressed in airway myocytes will help in defining the relative importance of these different channels [78, 79].

\section{Other channels}

A large number of sodium channels have been identified but relatively little information is available regarding their role (if any) in nonexcitable cells such as airway smooth muscle. In addition, a nonselective cation current has been demonstrated in airway myocytes [80] but its physiological significance remains uncertain.

\section{Conclusion}

The control of the contractile apparatus in a single airway myocyte is a complex process involving multiple conflicting signals in vivo. In order to achieve regulation of these influences, airway myocytes have developed a series of complex homeostatic mechanisms involving signalling through phospholipase $\mathrm{C}$, adenylyl cyclase and ion channel pathways. Crosstalk between these pathways is also important in achieving homeostasis. Understanding these processes is critically important. All of the currently available bronchodilator agents produce their effects by interaction with either receptors coupled to signalling pathways or the intracellular signalling pathways themselves. However, a number of targets (for example the nonvoltagedependent calcium entry mechanism in airway smooth 
muscle) exist for which no adequate therapeutic agents are currently in use. A fuller understanding of the importance of these pathways will potentially lead to the development of novel therapeutic agents for the treatment of diseases such as asthma.

\section{References}

1. Hall IP, Kotlikoff MI. Use of cultured airway myocytes to study airway responses. Am J Physiol 1995; 12: L1-L11.

2. Halayko AJ, Camoretti-Mercado B, Forsythe SM, et al. Divergent differentiation pathways in airway smooth muscle culture: induction of functionally contractile myocytes. Am J Physiol 1999; 276: L197-L206.

3. Widdop S, Daykin K, Hall IP. Expression of muscarinic $\mathrm{M}_{2}$ receptors in cultured human airway smooth muscle cells. Am J Respir Cell Mol Biol 1993; 9: 541-546.

4. Hall IP, Widdop S, Townsend P, Daykin K. Control of cyclic AMP content in primary cultures of human tracheal smooth muscle cells. Br J Pharmacol 1992; 107: 422428.

5. Yang CM, Chou S-P, Sung T-C, Chien H-J. Regulation of functional muscarinic receptor expression in tracheal smooth muscle cells. Am J Physiol 1991; 261: C1123C1129.

6. Halyoko AJ, Salari H, Ma X, Stephens NL. Markers of airway smooth muscle cell phenotype. Am J Physiol 1996; 270: L1040-L1051.

7. Hashimoto T, Hirata M, Ito Y. A role for inositol 1,4,5trisphosphate in the initiation of agonist-induced contraction of dog tracheal smooth muscle. Br J Pharmacol 1985; 86: 191-201.

8. Chopra LC, Twort CHC, Cameron IR, Ward JPT. Inositol 1,4,5-trisphosphate- and guanosine 5'- 0 -(3-thiophosphate)-induced $\mathrm{Ca}^{2+}$ release in cultured airway smooth muscle. Br J Pharmacol 1991; 104: 901-906.

9. Kotlikoff MI, Murray RK, Reynolds EE. Histainincinduced calcium release and phorbol antagonism in cultured airway smooth muscle cells. Am J Physiol 1987; 253: C561-C566.

10. Daykin K, Widdop S, Hall IP. Control of histamine induced inositol phospholipid hydrolysis in cultured human tracheal smooth muscle cells. Eur J Pharmacol 1993; 246: $135-140$.

11. Roffel AF, Meurs H, Zaagsina J, et al. Muscarinic acetylcholine receptors and control of smooth muscle tone. Trends in Pharmacol Sci 1994; 15: 407-408.

12. Janssen JL, Danial EE. Pre- and post-junctional muscarinic receptors in caninebronchi. Am J Physiol 1990; 259: L304-L314.

13. Watson N, Barnes PJ, Maclagan J. Actions of methoctramine, a muscarinic $\mathrm{M}_{2}$ receptor antagonist, on muscarinic and nicotinic cholinoceptors in guinea-pig airways in vivo and in vitro. Br J Pharmacol 1992; 105: 107-112.

14. Yang CM, Chou S-P, Wang Y-Y, Hsieh J-T, Ong R. Muscarinic regulation of cytosolic free calcium in canine tracheal smooth muscle cells: $\mathrm{Ca}^{2+}$ requirement for phospholipase C activation. Br J Pharmacol 1993; 110: 12391247.

15. Abela A, Daniel EE. Neural and myogenic effects of leukotrienes $\mathrm{C}_{4}, \mathrm{D}_{4}$ and $\mathrm{E}_{4}$ on canine bronchial smooth muscle. Am J Physiol 1994; 266: L414-L425.

16. Panettieiri RA, Murray RK, DePalo LR, Yadvish PA, Kotlikoff MI. A human airway smooth muscle cell line that retains physiological responsiveness. Am J Physiol 1989; 256: C329-C335.

17. Farmer SG, Ensore JE, Burch RM. Evidence that cultured airway smooth muscle cells contain bradykinin $\mathrm{B}_{2}$ and $\mathrm{B}_{3}$ receptors. Am J Respir Cell Mol Biol 1991; 4: 273277.

18. Marsh KA, Hill SJ. Bradykinin $\mathrm{B}_{2}$-receptor-mediated phosphoinositide hydrolysis in bovine cultured tracheal smooth muscle cells. Br J Pharmacol 1992; 107: 443447.

19. Yang CM, Yo Y-L, Hsich J-T, Ong R. 5-Hydroxytryptamine receptor-mediated phosphoinositide hydrolysis in canine cultured tracheal smooth muscle cells. Br J Pharmacol 1994; 111: 777-786.

20. Murray RK, Kotlikoff MI. Receptor-activated calcium influx in human airway smooth muscle cells. $J$ Physiol 1991; 435: 123-144.

21. Murray RK, Fleischmann BK, Kotlikoff MI. Receptoractivated $\mathrm{Ca}$ influx in human airway smooth muscle: use of Ca imaging and perforated patch-clamp techniques. $\mathrm{Am}$ J Physiol 1993; 264: C485-C490.

22. Hofmann T, Obukhov AG, Schaefer M, Harteneck C, Gudermann T, Schultz G. Direct activation of human TRPC6 and TRPC3 channels by diacylglycerol. Nature 1999; 397: 259-263.

23. Wheatley AP, Hall IP. Expression of homologues of the transient receptor potential (TRP) gene in primary cultured human airway smooth muscle cells. Br J Pharmacol 1999; 128: 122.

24. Hall IP, Daykin K, Widdop S. $\beta_{2}$-adrenoceptor desensilisation in cultured human airway smooth muscle. Clin Sci 1993; 84: 151-157.

25. Tomlinson PR, Wilson JW, Stewart AG. Salbutamol inhibits the proliferation of human airway smooth muscle cells grown in culture: relationship to elevated cAMP levels. Biochem Pharmacol 1995; 49: 1809-1819.

26. Pang L, Holland E, Knox AJ. Role of cyclo-oxygenase-2 induction in interleukin-1 $\beta$ induced attenuation of cultured human airway smooth muscle cell cyclic AMP generation in response to isoprenaline. Br J Pharmacol 1998; 125: 1320-1328.

27. Barries PJ, Dixon CMS. The effect of inhaled vasoactive intestinal peptide on bronchial hyperreactivity in man. $\mathrm{Am}$ Rev Respir Dis 1984; 130: 162-166.

28. O'Donnell M, Garippa RJ, Rinaldi N, et al. Ro25-1553: a novel long-acting vasoactive intestinal peptide agonist. Part 1: in vitro and in vivo bronchodilator studies. J Pharmacol Exp Ther 1994; 270: 1282-1288.

29. Torphy TJ, Hall IP. Cyclic AMP and the control of airway smooth muscle tone. In: Raeburn D, Giembycz MA, eds. Airways Smooth Muscle. Biochemical Control of Contraction and Relaxation. Basle, Birkhauser Verlag, 1994; pp. 215-233.

30. Yang CM, Chou S-P, Sung TC. Muscarinic receptor subtypes coupled to generation of different second messangers in isolated tracheal smooth muscle cells. $\mathrm{Br} J$ Pharmacol 1991; 104: 613-618.

31. Widdop S, Daykin K, Hall IP. Expression of muscarinic $\mathrm{M}_{2}$ receptors in cultured human airway smooth muscle cells. Am J Respir Cell Mol Biol 1993; 9: 541-546.

32. Sankary RM, Jones CA, Madison JM, Brown JK. Muscarinic cholinergic inhibition of cyclic AMP accumulation in airway smooth muscle: role of a pertussis toxin sensitive protein. Am Rev Respir Dis 1988; 138: 145-150.

33. Miura M, Belvisi MG, Stretton CD, Yacoub MH, Barnes PJ. Role of potassium channels in bronchodilator 
responses in human airways. Am Rev Respir Dis 1992; 146: $132-136$.

34. Kume H, Takai A, Tokuno H, Tomita T. Regulation of $\mathrm{Ca}^{2+}$-dependent $\mathrm{K}^{+}$channel activity in tracheal myocytes by phosphorylation. Nature 1989; 341: 152-154.

35. Kume H, Hall IP, Washabau RJ, Takagi K, Kotlikoff MI. $\beta$-Adrenergic agonists regulate $\mathrm{K}(\mathrm{Ca})$ channels in airway smooth muscle by cAMP-dependent and -independent mechanisms. J Clin Invest 1994; 93: 371-379.

36. Kume H, Graziano MP, Kotlikoff MI. Stimulatory and inhibitory regulation of calcium activated potassium channels by guanine nucleotide-binding proteins. Proc Natl Acad Sci USA 1992; 89: 11051-11055.

37. Kume H, Kotlikoff MI. Muscarinic inhibition of single $\mathrm{K}_{\mathrm{Ca}}$ channels in smooth muscle cells by a pertussis-sensitive G protein. Am J Physiol 1991; 261: C1204-C1209.

38. Jones TR, Charette L, Garcia ML, Kaczorowski GJ. Selective inhibition of relaxationof guinea-pig trachea by charybdotoxin, a potent $\mathrm{Ca}^{++}$activated $\mathrm{K}^{+}$channel inhibitor. J Pharmacol Exp Ther 1990; 255: 697-706.

39. Felbel J, Trockur B, Ecker T, Landgraf W, Hofmann F. Regulation of cytosolic calcium by cAMP and cGMP in freshly isolated smooth muscle cells from bovine trachea. J Biol Chem 1988; 263: 16764-16771.

40. Gunst SJ, Stropp JQ. Effect of Na-K adenosinetriphosphatase activity on relaxation of canine tracheal smooth muscle. J Appl Physiol 1988; 64: 635-641.

41. Hulks G, Mohammed AF, Jardine A, Connell JMC, Thomson NC. Circulating plasma concentrations of atrial natriuretic peptide and catecholamines in response to maximal exercise in normal and asthmatic subjects. Tho$\operatorname{rax} 1991$; 46: 824-828.

42. Robichaud A, Michoud MC, Hamet P, Du Souich P. Plasma atrial natriuretic peptide during spontaneous bronchoconstriction in asthmatics. Peptides 1995; 16: 653-656.

43. Hamad AM, Range S, Holland E, Knox AJ. Regulation of cGMP by soluble and particulate guanylyl cyclases in cultured human airway smooth muscle. Am J Physiol 1997; 273: L807-L813.

44. Buga GM, Gold ME, Wood KS, Chaudhuri G, Ignarro LJ. Endothelium derived nitric oxide relaxes nonvascular smooth muscle. Eur J Pharmacol 1989; 161: 61-72.

45. Yoshihara S, Nadel JA, Figini M, Emanueli C, Pradelles P, Geppetti P. Endogenous nitric oxide inhibits bronchoconstriction induced by cold-air inhalation in guinea pigs. Am J Respir Crit Care Med 1998; 157: 547-552.

46. Figini M, Ricciardolo FL, Javdan P, et al. Evidence that endothelium-derived relaxing factor released by bradykinin in the guinea pig trachea is nitric oxide. Am J Respir Crit Care Med 1996; 153: 918-923.

47. Turner NC, Lamb J, Worby A, Murray KJ. Relaxation of guinea pig trachea by cyclic AMP phosphodiesterase inhibitors and their enhancement by sodium nitroprusside. Br J Pharmacol 1994; 111: 1047-1052.

48. Felbel J, Trockur B, Ecker T, Landgraf W, Hofmann F. Regulation of cytosolic calcium by cyclic AMP and cyclic GMP in freshly isolated smooth muscle cells from bovine trachea. J Biol Chem 1988; 263: 16764-16771.

49. Prakash YS, Kannan MS, Sieck GC. Nitric oxide inhibits acetyl choline-induced intracellular calcium oscillations in porcine tracheal smooth muscle. Am J Physiol 1997; 272: L588-L596.

50. Kannan MS, Prakash YS, Johnson DE, Sieck GC. Nitric oxide inhibits calcium release from sarcoplasmic reticulum of porcine tracheal smooth muscle cells. Am J Physiol 1997; 272: L1-L7.

51. McGrogan I, Lu S, Hipworth S, et al. Mechanisms of cyclic nucleotide-induced relaxation in canine tracheal smooth muscle. Am J Physiol 1995; 268: L407-L413.

52. Jones KA, Wong GY, Jankowski M, Akao M, Warner DO. Cyclic GMP modulation of $\mathrm{Ca}^{2+}$ sensitivity in airway smooth muscle. Am J Physiol 1999; 276: L35-L40.

53. Alioua A, Huggins JP, Rousseau E. PKG-I $\alpha$ phosphorylates the $\alpha$-subunit and upregulates reconsitituted GKca channels from tracheal smooth muscle. Am J Physiol 1995; 268: L1057-L1063.

54. Yamakage M, Hirshman CA, Croxton TL. Sodium nitroprusside stimlates $\mathrm{Ca}^{2+}$-activated $\mathrm{K}^{+}$channels in porcine tracheal smooth muscle cells. Am J Physiol 1996; 270 : L338-L345.

55. Zhou H, Torphy TJ. Relationship between cyclic GMP accumulation and relaxation of canine trachealis induced by nitrovasodilators. $J$ Pharmacol Exp Ther 1991; 258: 972-978.

56. Nakane M, Arai K, Saheki S, Kuno T, Buechler W, Murad F. Molecular cloning and expression of cDNAs coding for soluble guanylyl cyclase from rat lung. J Biol Chem 1990; 265: 16841-16845.

57. Hill SJ, Kendall DA. Cross-talk between intracellular second messenger transduction systems. Drug News \& Perspectives 1992; 5: 39-48.

58. Hall IP, Hill SJ. $\beta$-Adrenoceptor stimulation inhibits histamine-stimulated inositol phospholipid hydrolysis in bovine tracheal smooth muscle. Br J Pharmacol 1988; 95: 1204-1212.

59. Hall IP, Donaldson J, Hill SJ. Inhibition of histaminestimulated inositol phospholipid hydrolysis by agents which elevate cyclic AMP levels in bovine tracheal smooth muscle. Br J Pharmacol 1989; 97: 603-613.

60. Hall IP, Donaldson J, Hill SJ. Modulation of fluoroaluminate-induced inositol phosphate formation by increases in tissue cyclic AMP content in bovine tracheal smooth muscle. Br J Pharmacol 1990; 100: 646-651.

61. Madison JM, Brown JK. Differential inhibitory effects of forskolin, isoproterenol, and dibutyryl cyclic adenosine monophosphate on phosphoinositide hydrolysis in canine tracheal smooth muscle. J Clin Invest 1988; 82: 14621465.

62. Hall IP, Donaldson J, Hill SJ. Modulation of carbacholinduced inositol phosphate formation in bovine tracheal smooth muscle by cyclic AMP phosphodiesterase inhibitors. Biochem Pharmacol 1990; 39: 1357-1363.

63. Billington CK, Hall IP, Mundell SJ, et al. Inflammatory and contractile agents sensitise specific adenylyl cyclase isoforms in human airway smooth muscle. Am J Respir Cell Mol Biol 1999; 21: 597-606.

64. Beavo JA. Cyclic nucleotide phosphodiesterases: functional implications of multiple isoforms. Physiol Rev 1995; 75: 725-748.

65. Billington CK, Joseph SK, Swan C, Scott MGH, Jobson TM, Hall IP. Modulation of human airway smooth muscle proliferation by type 3 phosphodiesterase inhibition. Am J Physiol 1999; 276: L412-L419.

66. Torphy TJ, Undem BJ. Phosphodiesterase inhibitors: new opportunities for the treatment of asthma. Thorax 1991; 46: 512-523.

67. Nicholson CD, Challiss RAJ, Shahid M. Differential modulation of tissue function and therapeutic potential of selective inhibitors of cyclic nucleotide phosphodiesterase isoenzymes. Trends Pharmacol Sci 1991; 12: 19-27.

68. Tomasik M, Boyle JP, Worley FJ III, Kotlikoff MI. Contractile agonists activate voltage-dependent calcium 
channels in airway smooth muscle cells. Am J Physiol 1992; 263: C106-C113.

69. Yamakage M, Hirshman CA, Croxton TI. Cholinergic regulation of voltage-dependent $\mathrm{Ca}^{2+}$ channels in porcine tracheal smooth muscle cells. Am J Physiol 1995; 269: L776-L782.

70. Fleischmann BK, Wang XY, Pring M, Kotlikoff MI. Voltage-dependent calcium currents and cytosolic calcium in equine airway myocytes. $J$ Physiol (Lond) 1996; 492: 347-358.

71. Worley JF, Kotlikoff MI. Dihydropyridine-sensitive single calcium channels in airway smooth muscle cells. Am J Physiol 1990; 259: L468-L480.

72. Kotlikoff MI. Calcium currents in isolated canine airway smooth muscle cells. Am J Physiol 1988; 254: C793C801.

73. Kotlikoff MI, Wang Y-X. Calcium release and calciumactivated chloride channels in airway smooth muscle cells. Am J Respir Crit Care Med 1998; 158: S109-S114.

74. McCann JD, Welsh MJ. Calcium activated potassium channels in canine airway smooth muscle. $J$ Physiol (Lond) 1986; 372: 113-127.
75. Kotlikoff MI. Potassium currents in canine airway smooth muscle cells. Am J Physiol 1990; 259: L384-L395.

76. Boyle JP, Tomasic M, Kotlikoff MI. Delayed rectifier potassium channels in canine and porcine airway smooth muscle cells. J Physiol (Lond) 1992; 447: 329-350.

77. Isaac L, McArdle S, Miller NM, Foster RW, Small RC. Effects of some $\mathrm{K}^{+}$channel inhibitors on the electrical behaviour of guinea-pig isolated trachealis and on its responses to spasmogenic drugs. Br J Pharmacol 1996; 117: $1653-1662$.

78. Dworetzky SI, Trojnacki JT, Gribkoff VK. Cloning and expression of a human large-conductance calcium-activated potassium channel. Mol Brain Res 1994; 27: 189193.

79. Adda S, Fleischmann BK, Freedman BD, Yu M-F, Hay DWP, Kotlikoff MI. Expression and function of voltagedependent potassium channel genes in human airway smooth muscle. J Biol Chem 1996; 271: 13239-13243.

80. Fleischmann BK, Wang Y-X, Kotilikoff MI. Muscarinic activation and calcium permeation of nonselective cation currents in airway myocytes. Am J Physiol 1997; 272: C341-C349. 